\title{
PKM PELATIHAN MENJAWAB SOAL UJIAN NASIONAL BAHASA INGGRIS MELALUI METODE PREDICTING DAN SCANNING PADA SISWA MTs NURUL HIKAM KAPONGAN KABUPATEN SITUBONDO
}

\author{
PKM TRAINING ANSWERING THE QUESTION ITEMS OF ENGLISH \\ NATIONAL EXAM THROUGH PREDICTING AND SCANNING METHODS \\ FOR STUDENTS OF MTS NURUL HIKAM KAPONGAN SITUBONDO
}

\author{
Dwi Taurina Mila Wardhani \\ Sastra Inggris, Fakultas Sastra, Universitas Abdurachman Saleh Situbondo \\ Email : dwimeela@gmail.com
}

\begin{abstract}
Abstrak: Kegiatan ini dilaksanakan sebagai salah satu upaya pemberian solusi atas permasalahan yang ada pada mitra yaitu MTS Nurul Hikam, dalam rangka mendukung upaya agar siswanya mampu menjawab cepat dan benar soal ujian nasional bahasa Inggris yang berbasis komputer. Hasil pelatihan ini diharapkan dapat meningkatkan kualitas siswa dan nilai akhir ujian nasional mereka. Dari hasil observasi awal yang telah dilakukan, MTS Nurul Hikam Kesambirampak Kapongan Situbondo terpilih menjadi mitra kegiatan PKM dikarenakan kemampuan dan pemahaman siswa dalam pelajaran bahasa Inggris yang kurang sehingga membuat nilai Bahasa Inggris mereka rendah, yang dilihat dari hasil ujian tryout mereka. Untuk mengupayakan peningkatan nilai bahasa Inggris siswa maka haruslah diberikan pelatihan trik menjawab soal bahasa Inggris. Siswa kelas IX akan mendapatkan pelatihan dalam menjawab soal-soal ujian bahasa Inggris berbasis komputer dengan menggunakan teknik predicting dan scanning. Pelatihan ini dilaksanakan kurang lebih selama tiga bulan dimana siswa diberikan bimbingan secara detail tentang trik menjawab soal bahasa Inggris. Selama pelatihan, siswa juga mendapat kesempatan untuk berdiskusi dan bertanya jika ada permasalahan untuk mencapai solusi yang tepat. Luaran yang diharapkan dari pelatihan ini siswa belajar mandiri melalui soal-soal latihan Ujian Nasional.
\end{abstract}

Kata Kunci: Ujian Nasional, Bahasa Inggris, pelatihan, scanning dan predicting, MTS Nurul Hikam

Abstract: This activity was carried out as an effort to provide solutions to existing problems with partner, namely MTS Nurul Hikam, so that its students are able to answer quickly and correctly the computer-based English national exam questions. The results of the training are expected to improve the quality of students and their final national examination scores. From the results of preliminary observation that has been made, MTS Nurul Hikam Kesambirampak Kapongan Situbondo was chosen to be this community srvice partner due to its students' lack of ability and understanding in English lessons which made their English scores low, as seen from the results of their tryout exams. To strive to 
improve students' English grades, the students must be given tricks training in answering English naquetional exam stions. Class IX students received a training in answering computer-based English exam questions using predicting and scanning techniques. The training was carried out for approximately three months where students were given detailed guidance on tricks to answer English questions. During the training, students also got the opportunity to discuss and ask if there were problems to reach the right solution. The expected outcome of this training is that students learn independently through practice questions on the National Examination.

Keywords: National Examination, Engllish, predicting and scanning, training, MTS Nurul Hikam

\section{PENDAHULUAN}

Bahasa Inggris sebagai salah satu bahasa asing yang resmi di ajarkan di jenjang pendidikan formal di Indonesia menjadi salah satu tolak ukur kemampuan bagi siswa. Peningkatan mutu layanan pendidikan membutuhkan penilaian sebagai indikator kinerja. Ujian Nasional adalah salah satu indikator untuk mengukur ketercapaian standar kompetensi lulusan pada mata pelajaran tertentu secara nasional sebagai bagian dari sistem evaluasi pendidikan. Menurut PP no 32 tahun 2013 "Penilaian hasil belajar digunakan untuk menilai pencapaian kompetensi peserta didik, bahan penyusunan laporan kemajuan hasil belajar, dan memperbaiki pembelajaran.

Mulai tahun ajaran 2015 Kementrian Pendidikan menghadirkan dua opsi untuk melaksanakan Ujian Nasional, yaitu UN berbasis kertas (seperti yang dilakukan di tahun-tahun sebelumnya) dan UN berbasis komputer (Computerbased Test/CBT).

Sehubungan dengan hal itu maka perlu mempersiapkan peserta didik agar memperoleh standar nilai yang di inginkan oleh sekolah. Latihan dan pembiasaan untuk mengerjakan soal-soal ujian nasional sangatlah penting. Lebih jauh peserta didik harus terbiasa mengerjakan latihan soal-soal ujian menggunakan komputer. Khusus untuk mata pelajaran bahasa Inggris yang masih dianggap sulit oleh 


\section{INTEGRITAS : Jurnal Pengabdian}

Vol 3, No 2, Desember 2019

sebagian besar siswa di MTs Nurul Hikam Kapongan perlu diajarkan trik bagaimana menjawab soal-soal ujian tersebut secara cepat dan tepat.

MTS Nurul Hikam Kapongan Situbondo merupakan salah satu sekolah swasta di Situbondo. MTS Nurul Hikam Kapongan merupakan Madrasah Stanawiyah yang setara dengan sekolah menengah pertama yang diselenggarakan oleh Kementrian Agama. Letaknya berada di Desa Kesambirampak Kecamatan Kapongan Kabupaten Situbondo. Sekolah ini berdiri pada tahun 1973. MTS Nurul Hikam Kapongan sudah terakreditasi A. Total jumlah pengajar di sekolah ini adalah 26 orang. Namun walaupun MTS ini sudah berakreditasi A guru pengampu pelajaran Bahasa Inggris yang berlatar belakang pendidikan bahasa Inggris hanyalah 1 orang. Lebih jauh kebanyakan dari siswa tidak memiliki buku pegangan ataupun LKS bahasa Inggris sehingga sistem pembelajaran yang digunakan yaitu dengan cara mencatat dipapan tulis materi yang akan di ajarkan. Hal ini membuat siswa kurang terlatih untuk menjawab soal bahasa Inggris khususnya bagi siswa kelas IX yang akan menempuh Ujian Nasional. Hal ini terlihat dari hasil ujian sekolah dan ujian tryout yang telah dilaksanakan, dimana nilai siswa MTS Nurul Hikam Masih jauh diatas rata-rata yang ingin dicapai. Sehingga dapat disimpulkan permasalahan yang ditemui di sekolah mitra adalah sebagai berikut:

- Rendahnya pemahaman siswa dalam pelajaran Bahasa Inggris.

- Hasil nilai ujian tryout yang rendah.

Visualisasi MTS Nurul Hikam dapat dilihat dari gambar-gambar berikut:

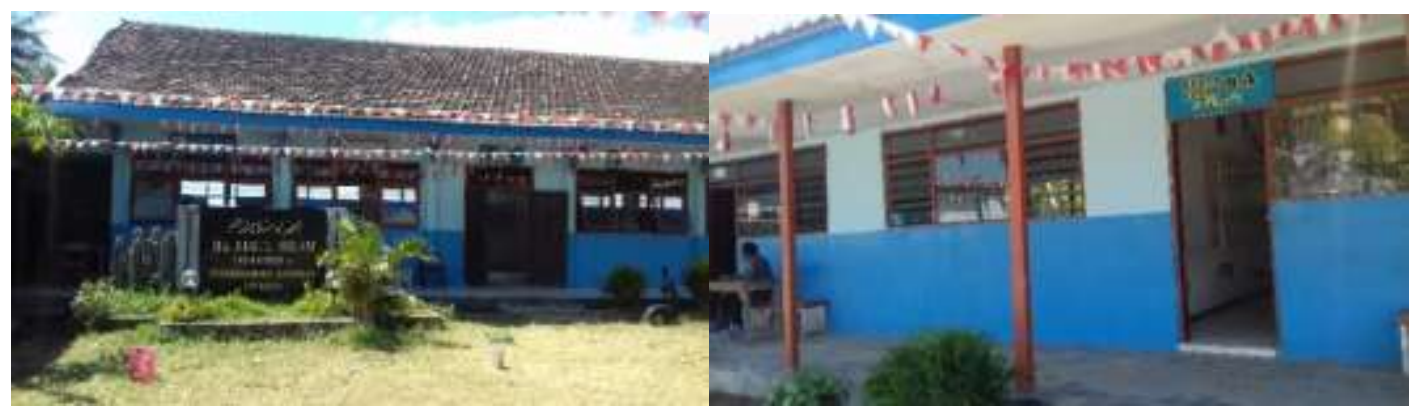

Gambar 1: Visualisiasi MTS Nurul Hikam Kapongan 


\section{INTEGRITAS : Jurnal Pengabdian}

Dari permasalahan tersebut diberikan solusi untuk menyelesaikan masalah yang dihadapi oleh MTs Nurul Hikam Kapongan Situbondo yaitu:

a. Memberikan pelatihan trik cepat dan tepat menjawab soal-soal ujian nasional pada siswa.

b. Memberikan pendampingan kepada siswa selama proses pembelajaran.

Luaran yang hendak diupayakan dan dicapai dengan pemberian solusi ini adalah meningkatnya nilai pelajaran Bahasa Inggris siswa dalam ujian khususnya nilai Ujian Nasional.

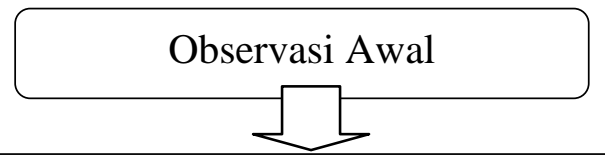

\section{Permasalahan}

1. Rendahnya pemahaman siswa dalam pelajaran Bahasa Inggris.

2. Hasil nilai ujian yang rendah

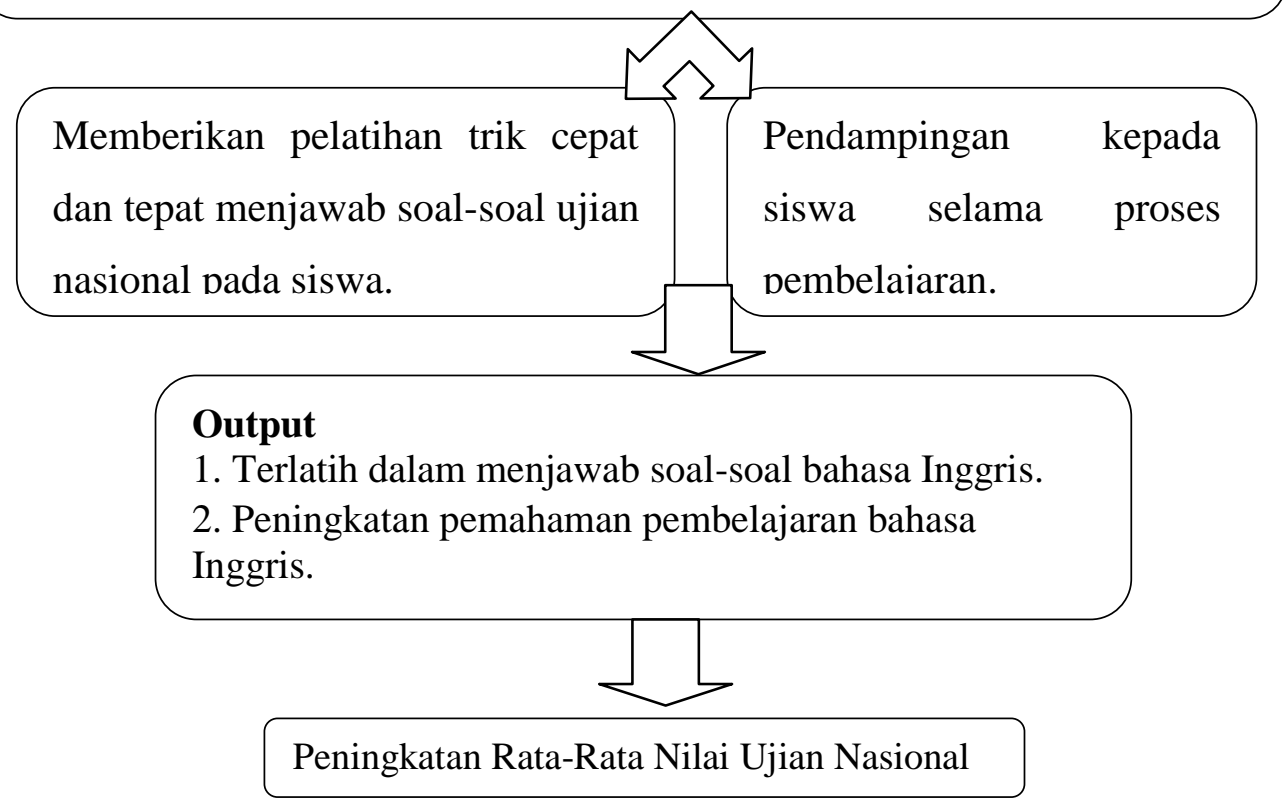

Gambar 2. Gambaran Iptek yang akan Dilaksanakan pada Mitra 
INTEGRITAS : Jurnal Pengabdian

Vol 3, No 2, Desember 2019

ISSN 2580-7978 (Cetak) ISSN 2615-0794 (Online)

\section{METODE PELAKSANAAN}

Dalam pelaksanaan kegiatan Program Kemitraan Masyarakat, metodemetode yang akan diterapkan adalah sebagai berikut:

\section{Tahap Persiapan}

Tahap persiapan mencakup beberapa langkah kegiatan yaitu pertama: observasi awal, kedua: pemilihan pelaksana dan pembantu pelaksana kegiatan, dan yang ketiga adalah penetapan waktu, tempat, dan anggota pelatihan.

Observasi awal dilakukan untuk memilih sekolah yang akan dijadikan mitra. Kriteria pemilihan mitra adalah sekolah SMP/MTs sederajat yang ada di Situbondo yang dirasa memiliki permasalahan dalam nilai ujian bahasa Inggris Siswa, khususnya siswa kelas IX yang akan mengikuti ujian nasional.

Pelaksana kegiatan adalah 1 orang dosen untuk mendampingi para siswa dalam proses pelatihan. Dalam hal ini akan diberikan metode trik menjawab soal ujian nasional dengan cepat dan tepat walaupun ada keterbatasan dalam pemahaman bahasa.

Setelah sekolah mitra setuju untuk bekerjasama, maka waktu, tempat, dan anggota pelatihan segera ditetapkan. Materi untuk pelatihan juga dipersiapkan pada tahap ini.

\section{Tahap Pelaksanaan}

Tahap pelaksanaan dibagi menjadi dua yaitu pelatihan dan pendampingan. Pelaksanaan kegiatan pelatihan adalah selama empat kali pertemuan dengan detil sebagai berikut:

- Pertemuan I: Pengenalan dan tujuan kegiatan. Memberikan materi predicting dan scanning.

- Pertemuan II: Pemberian contoh bagaimana trik menjawab soal bahasa Inggris dengan memperkenalkan jenis-jenis soal yang umumnya akan ditanyakan dalam ujian nasional.

- Pertemuan III: Pendampingan latihan soal dilanjutkan pembahasannya.

- Pertemuan IV: Posttest 


\section{INTEGRITAS : Jurnal Pengabdian}

\section{Tahap Tindak Lanjut Kegiatan}

Setelah pelatihan selesai, pelaksana program melakukan beberapa kegiatan sebagai wujud dari tindak lanjut kegiatan pelatihan. Tahap tindak lanjut ini meliputi evaluasi dan tindak lanjut pelaksanaan pelatihan pembelajaran dalam menjawab soal bahasa Inggris. Pada tahap ini, pelaksana program mengevaluasi kegiatan pelatihan yang telah dilaksanakan. Semua masalah atau hambatan yang muncul saat kegiatan pelatihan akan dibahas. Setelah itu, pelaksana kegiatan mengumpulkan data apakah ada kemajuan dalam kemampuan menjawab soal bahasa Inggris melalui posttest.

\section{Persiapan:}

a. Observasi awal

c. Penetapan waktu, tempat, dan anggota pelatihan

Pelaksanaan:

a. Pelatihan

b. Pendampingan

Tindak Lanjut:

Evaluasi kegiatan pelatihan

Gambar 3. Alur Pelaksanaan PKM

\section{HASIL DAN PEMBAHASAN}

Kegiatan Program Kemitraan Masyarakat (PKM) ini dilaksanakan melalui beberapa tahapan, yaitu tahap observasi awal, tahap pelaksannaan Kegiatan, dan tahap tindak lanjut kegiatan. Tahap observasi awal menghasilkan persetujuan kerjasama dengan mitra, perumusan masalah, dan target serta luaran yang ingin dicapai. Pada tahap pelaksanaan kegiatan, kegiatan yang dihasilkan adalah kegiatan persiapan dan pelasanaan pelatihan. Pada tahap persiapan, ditentukan bahan materi yang akan diberikan dan peserta pelatihan. Pada tahap pelaksanaan, 


\section{INTEGRITAS : Jurnal Pengabdian}

kegiatan yang dihasilkan adalah pelatihan trik menjawab soal Ujian Nasional Bahasa Inggris pada siswa Mts Nurul Hikam Kapongan Situbondo. Tahap terahir dari kegiatan PKM ini adalah tahap tindak lanjut kegiatan yang menghasilakan evaluasi kegiatan dan tindak lanjut dari pelaksanaan pelatihan.

\section{Tahap Observasi Awal}

Pada tahap ini, pelaksanaan program menghasilkan persetujuan kerjasama dengan mitra terpilih, yaitu MTs Nurul Hikam Kapongan Situbondo. Permasalahan utama adalah kurangnya kemampuan siswa dalam pelajaran bahasa Inggris yang mengakibatkan nilai ujian bahasa Inggris siswa tidak mencapai nilai rata-rata yang diinginkan.

Setelah menganalisis permasalahan yang ada, pelaksana program sampai pada solusi untuk memecahkan masalah tersebut. Hal ini ditujukan agar MTs Nurul Hikam dapat meningkatkan kemampuan siswa khususnya dalam pelajaran bahasa Inggris agar dapat mencapai nilai yang diharapkan. Setelah memutuskan memilih MTs Nurul Hikam Kapongan Situbondo sebagai mitra, maka pelaksanaan kegiatan membuat perjanjian kerja sama. Peran mitra disini adalah menentukan waktu dan tempat pelaksanaan pelatihan, dan memberikan perizinan terkait dengan pelaksanaan pelatihan trik menjawab soal ujian nasional bahasa Inggris pada siswa MTs Nurul Hikam Kapongan.

\section{Tahap Pelaksanaan kegiatan}

\section{a. Persiapan Pelatihan menjawab Soal Ujian Nasional Bahasa Inggris.}

Pada tahap ini, pelaksana kegiatan memutuskan untuk menjadi narasumber berkaitan dengan materi, yaitu bagai mana cara menjawab cepat dan tepat soal bahasa Inggris pada ujian nasional.

Disini ketua pelaksana PKM sebagai narasumber inti. Ada beberapa alasan yaitu ketua pelaksana PKM adalah ahli di bidang tehnik pembelajaran yang fokusnya pada pengajaran bahasa Inggris. Yang mana bidang fokus keahliannya adalah mengajar mata kuliah reading dan grammar. 


\section{Pelaksanaan Pelatihan Menjawab Soal Ujian Ujian Nasional Bahasa Inggris.}

Kegiatan pelatihan ini diadakan selama dua minggu, yaitu dilaksanakan pada tanggal 8,10, 15 dan 17 April 2019. Setiap minggunya dua kali pertemuan yaitu pada hari Senin dan hari Rabu. Di MTs Nurul Hikam terdapat 3 kelas untuk kelas IX, dua kelas putri dan satu kelas putra. Setiap kelasnya pelatihan dan pendampingan di laksanakan selama 60 menit. Materi yang diberikan diambil dari lembar kerja latihan soal-soal persiapan Ujian yang dimiliki siswa. Pertemuan I

Pada pelatihan pertemuan pertama dikenalkan trik metode predicting dan scanning kepada siswa untuk menjawab soal pilihan di ujian nasional. Kemudian dilanjutkan dengan mencoba berlatih menjawab 10 soal ujian nasional yang terdapat pada lembar kerja siswa yang mereka miliki. Pada pertemuan pertama ini siswa masih kebingungan dalam menjawan soal-soal. Pembahasan dilakukan dengan menggunakan trik menjawab predicting dan scanning. Kemudian siswa diminta melanjutkan lagi mengerjakan 10 soal lanjutan seperti yang telah dicontohkan. Dari hasil pembahasan siswa mulai mengerti bagaimana cara menjawab soal dengan cepat dan tepat. Mereka tampak senang dan memberi tanggapan ternyata menjawab soal bahasa Inggris tidak sesulit yang mereka anggap selama ini.

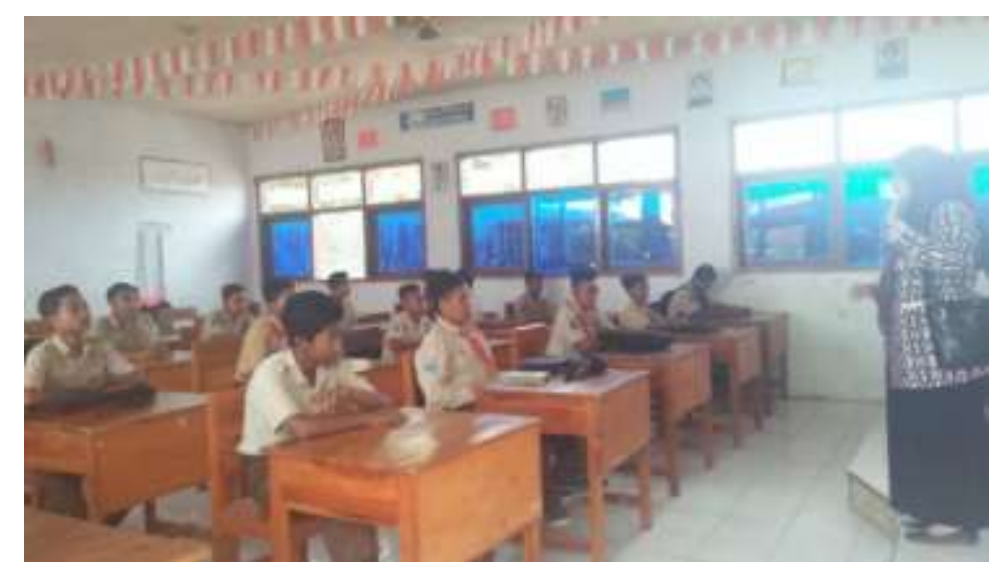

Gambar 4. Memberikan perkenalan materi 


\section{INTEGRITAS : Jurnal Pengabdian}

\section{Pertemuan II}

Pada pertemuan kedua dimulai dengan meminta siswa mengerjakan soal ujian nasional pada lembar kerja siswa yang difokuskan pada materi bagaimana menjawab soal dari macam-macam teks yang disajikan masih dengan menggunakan tehnik yang telah diajarkan yaitu predicting dan scanning.

Pada pertemuan kedua ini ditemukan bahwa banyak siswa yang tidak mengerti isi dari teks bacaan sehingga sulit untuk menjawab soal yang diberikan. Melalui technik predicting dan scanning dengan mencari kata kunci pertanyaan yang diberikan lebih memudahkan siswa dalam menebak jawaban soal ujian nasional.

\section{Pertemuan III}

Fokus pelatihan pada pertemuan ketiga adalah pada materi soal ujian nasional berupa teks pengumuman dan tanda peringatan atau larangan. Pada pertemuan ketiga ini ditemukan bahwa siswa lebih mudah menerapkan trik predicting dan scanning untuk menjawab soal ujian nasional dikarenakan teks bacaan tersebut pendek dan mudah ditebak. Berbeda dengan soal teks descriptive, recount, narrative, procedure, atau report yang cenderung lebih panjang dan diperlukan kejelian dalam menjawab soal-soal.

Diahir pertemuan ketiga siswa diminta untuk menjawab soal latihan sebanyak sepuluh soal dengan perpaduan soal yang telah dipelajari secara langsung. Ditemukan bahwa siswa mulai mengerti dan paham bagaimana trik menjawab soal walaupun mereka tidak mengerti kosa kata bahasa Inggris pada teks bacaan tersebut.

\section{Pertemuan IV}

Pada pertemuan ke empat dilaksanakan posttest untuk mengetahui peningkatan kemampuan bahasa Inggris siswa kelas IX dalam menjawab dan memprediksi dengan tepat dan cepat soal-soal ujian nasional bahasa Inggris 


\section{INTEGRITAS : Jurnal Pengabdian}

melalui trik predikting dan scanning yang telah di ajarkan. Kegiatan posttest ini dilakukan di laboratorium komputer, dimana soal yang digunakan telah disediakan oleh sekolah menggunakan sistem komputer.

Dari hasil posttest di temukan bahwa sekitar 60\% siswa dari total 70 siswa sudah mencapai nilai rata-rata yang diharapkan yaitu minimal 60. Sedangkan 40\% mahasiswa masih dibawah nilai yang diharapkan. Namun mereka sudah mulai paham bagaimana trik cara menjawab soal jika mereka tidak mengerti sekali dengan soal yang dimaksud.

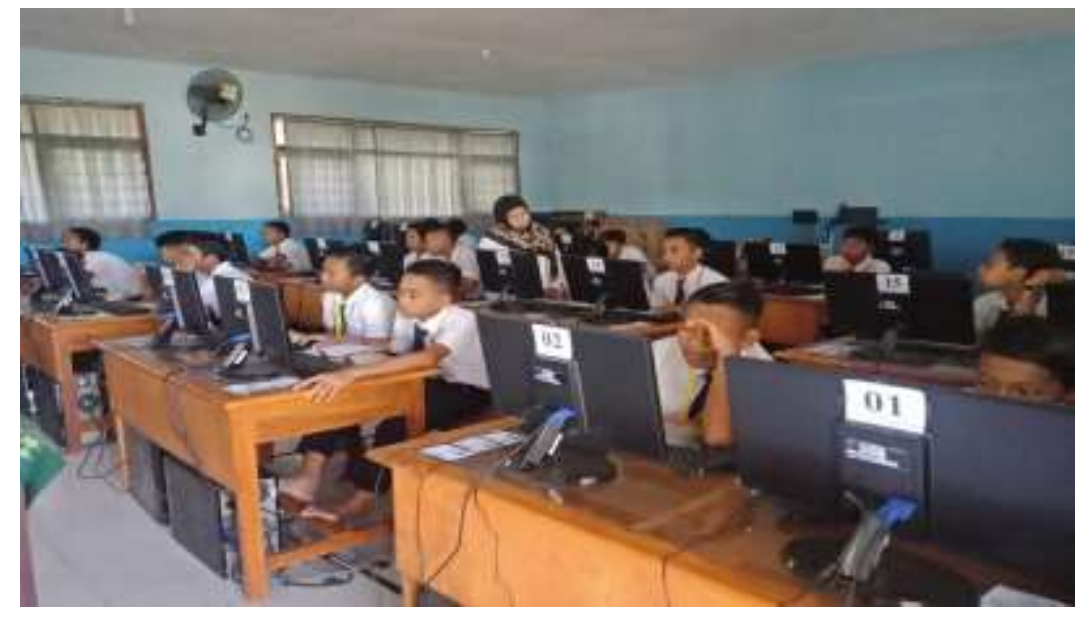

Gambar 5. Kegiatan Posttest

\section{Tahap Tindak Lanjut Kegiatan}

Tahap ini terdiri dari evaluasi dan tindak lanjut dari pelaksanaan pelatihan. Kegiatan evaluasi dilakukan setelah kegiatan pelatihan dilaksanakan , di kampus 1 Universitas Abdurachman Saleh Situbondo. Kegiatan ini bertujuan untuk melihat bagaimana pelaksanaan pelatihan, apakah berjalan dengan lancar atau tidak serta masalah apa saja yang terjadi pada saat pelatihan, seperti perihal penyebab keterlambatan beberapa peserta saat pelatihan dan kurang efektifnya waktu pelaksanaan kegiatan. Selain itu, kegiatan evaluasi ini juga digunakan sebagai tolak ukur untuk mengetahui minat dan respon para peserta pelatihan tentang trik menjawab soal ujian bahasa Inggris. 


\section{INTEGRITAS : Jurnal Pengabdian}

Dari kegiatan evaluasi didapatkan hasil bahwa minat dan respon peserta pelatihan sangat positif. Mereka sangat mengapresiasi kegiatan tersebut dan senang karena mendapatkan pengalaman baru dan ilmu baru, sehingga membantu mereka untuk lebih mudah menjawab soal-soal pilihan ganda bahasa Inggris melalui trik menjawab yang diajarkan.

Luaran yang dicapai melaui kegiatan pelatihan trik menjawab soal ujian nasional bahasa Inggris di MTs Nurul Hikan Kapongan Situbondo adalah sebagai berikut:

1. Pelatihan trik menjawab soal ujian nasional bahasa Inggris.

2. Publikasi ilmiah berupa artikel jurnal ilmiah nasional.

\section{KESIMPULAN DAN SARAN}

Dari kegiatan pengabdian ini disimpulkan bahwa diperlukan adanya pelatihan untuk menjawab soal-soal pilihan ganda dalam pelajaran bahasa Inggris bagi siswa untuk persiapan ujian nasional. Adapun cara yang bisa ditempuh meliputi:

1. Pelatihan trik cepat dan tepat menjawab soal-soal Ujian Nasional bahasa Inggris dengan teknik predicting dan scanning pada siswa MTs Nurul Hikam Kapongan.

2. Pendampingan pada siswa dalam kegiatan latihan menjawab soal-soal Ujian Nasional bahasa Inggris.

Kegiatan pelatihan ini sangat bermanfaat sekali bagi siswa. Maka dari itu, akan lebih baik lagi jika guru menerapkan teknik latihan yang sama sebagai bentuk tindak lanjut dari pelatihan yang telah dilakukan. Pelatihan ini dapat dilakukan lebih lama, melalui pendampingan lanjutan dari guru bahasa Inggris sekolah yang bersangkutan. 
INTEGRITAS : Jurnal Pengabdian

Vol 3, No 2, Desember 2019

ISSN 2580-7978 (Cetak) ISSN 2615-0794 (Online)

\section{DAFTAR PUSTAKA}

Kemdikbud. (2019). Informasi UN dan USBN. (Online)

https://un.kemdikbud.go.id

Mikulecky, Beatrice S. (1986). Reading Power. Addison-Wesley Publishing Company.

Purwanto, Heri. (2018). Kupas Tuntas UN Bahasa Inggris. Fokus 